\title{
The Institutional Framework of the EAC
}

\author{
Wilbert T.K. Kaahwa
}

\subsection{Introduction}

\subsubsection{Conceptual Background}

In the law of international organizations such as the United Nations (UN), continental organizations such as the European Union (EU) and the African Union (AU) and regional organizations including the Association of South East Asian Nations (ASEAN), the Common Market for Eastern and Southern Africa (COMESA) and the Southern African Development Community (SADC) the term "institutional framework" often refers to the legal framework that guides the pursuit of such organizations' objectives. The term can also refer to the systems of formal laws, regulations, and procedures, and informal conventions, customs, and norms that shape socioeconomic activity and behavior. However for the purposes of this book, this Chapter will only highlight the formal organizational set-up established by the Treaty for the Establishment of the East African Community ("the Treaty"). The second part, the legal framework of the EAC, will be discussed in Chapter 3 .

The importance and relevance of the institutional framework in the East African Community (EAC) can be traced to three facts. Firstly, the EAC has revived an inter-state co-operation system, whose historical antecedents and systematic development between 1967 and 1977 had given rise to an elaborate organizational framework of organs and service commissions. The Treaty for East African Co-operation 1967 had established institutions such as the East African Authority, ${ }^{1}$ the East African Legislative Assembly, ${ }^{2}$ Ministers of the Community, ${ }^{3}$ the Common Market Council, ${ }^{4}$ the Communications Council, ${ }^{5}$ the Economic Consultative and Planning Council, ${ }^{6}$ the Finance Council ${ }^{7}$

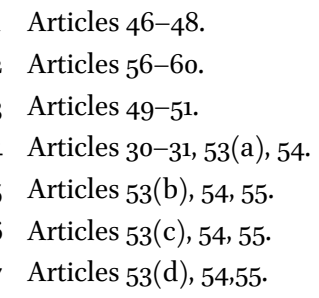


and the Research and Social Council; ${ }^{8}$ corporations such as the East African Airways Corporation, the East African Harbours Corporation, the East African Railways Corporation, the East African Posts and Telecommunications Corporation; ${ }^{9}$ judicial bodies such as the Court of Appeal for East Africa; ${ }^{10}$ the East African Industrial Court;"11 specialized bodies such as the East African Development Bank, ${ }^{12}$ the East African Community Service Commission ${ }^{13}$ and the East African Tax Board; $;^{14}$ and specialized departments, and services including the East African Medical Research Council and the East African Trypanosomiasis Institute. ${ }^{15}$

Secondly, the renewal and reconceptualization of co-operation among the United Republic of Tanzania, the Republic of Kenya and the Republic of Uganda in 1993 underscored the importance of an institutional framework. This renewal obliged the countries to explore and identify further areas for future co-operation and to work out concrete arrangements for co-operation, ${ }^{16}$ and therefore the need for an institutional framework became inevitable. This was reflected in the institution-creating overtones of the Agreement for the Establishment of The Permanent Tripartite Commission for Co-operation Between the Republic of Uganda, the Republic of Kenya and the United Republic of Tanzania ${ }^{17}$ and the Protocol on the Establishment of a Secretariat of The Permanent Tripartite Commission for Co-operation Between the Republic

\footnotetext{
$8 \quad$ Articles $53(\mathrm{e}), 54,55$.

9 Articles 71-79.

10 Articles 80-81.

11 Article 85.

12 Articles 21-22.

13 Articles 62-64.

14 Article 88.

15 East African Community, The East African Community; A Handbook 1972, Arusha, East African Community Information Division, 1970.The bodies and institutions included the Meteorological Department, the Freshwater Fisheries Organisation, the Industrial Research Organisation, the Institute of Malaria and Vector-Borne Diseases, the Institute for Medical Research, the Leprosy Research Institute, the Marine Fisheries Research Organisation, the Pesticides Research Organisation, the Agriculture and Forestry Research Organisation, the Trypanosomiasis Research Organisation, the Tuberculosis Investigation Centre, the Veterinary Research Organisation and the Virus Research Institute.

16 See Article 14.02 of The East African Community Mediation Agreement 1984.

17 Agreement for the Establishment of a Permanent Tripartite Commission for Co-operation Between the Republic of Kenya, The United Republic of Tanzania and the Republic of Uganda; see particularly Articles 1-5.
} 
of Uganda, the Republic of Kenya and the United Republic of Tanzania. ${ }^{18}$ Jointly, these instruments established a Permanent Tripartite Commission for Co-operation and a Secretariat.

Thirdly, the Community is a creature of modern dynamics in regionalism. According to Heitne "the new regionalism differs from the old regionalism (which was based on security interests in the bi-polar cold war context) in that it is a spontaneous process from within a region, is more comprehensive and multi-dimensional and encourages non-state actors and incorporates issues of accountability and legitimacy." 19 The EAC has grown as a channel for economic integration rather than as a consequence of mainly political solidarity as did, for example, other erstwhile organizations in Africa. ${ }^{20} \mathrm{New}$ regionalism necessitates organized structures for the purpose of effective and sustained realization of objectives. Indeed McCormick, with specific reference to the $\mathrm{EU}$, argues that, "integration is effectively driven by institutionalized structures. For example, the European Union has evolved and is driven by an elaborate structure consisting of the European Commission, the Council of Ministers, the European Parliament, the European Court of Justice, the European Council and specialized agencies."21

In its objectives as provided under the Treaty, and unlike the situation that obtained under the defunct East African Community (1967-1977), its predecessor the East African Common Services Organisation (1961-1967), and the colonial arrangement under the East African High Commission (1947-1961), the current integration process aims at achieving more than trade liberalization and harmonization in infrastructure and services. To use Amerasinghe's approach to the classification of international organizations, the EAC is "an inter-governmental, supra-national and closed organization"22 that seeks to

18 Ibid., Article 5; See also The Protocol on the Establishment of a Secretariat of The Permanent Tripartite Commission for Co-operation Between The Republic of Uganda, The Republic of Kenya and The United Republic of Tanzania.

19 Bjorn Heitne, Development Regionalism in New Directions In Development Economics (Growth, Environmental Concerns and Government in the 199os) Ed by Mats Lundahl and Benno J. Ndulu, London Routledge, 1996 pp. 160-164.

2o Such as The Organisation of African Unity and the Southern African Development Co-ordination Conference.

21 John McCormick, The European Union, Politics and Policies 4th Edn, (Philadelphia, Westview Press 2008), pp. 109-226.

22 C.F. Amerasinghe, Principles of the Institutional Law of International Organizations, 2nd edn, Cambridge, Cambridge University Press, 1996 pp. 9-13; See also Henry G. Schermers and Niels M. Blokker, International Institutional Law, The Hague, Martinus Nijhoff 
widen and deepen integration with the systematic establishment of a Customs Union, a Common Market, a Monetary Union and ultimately a Political Federation..$^{23}$ It also emphasizes strong participation of the private sector and civil society in its co-operation programmes and activities. ${ }^{24}$ The accomplishment of these objectives requires an elaborate and functionally-purposed institutional framework.

\subsubsection{Legal Basis for the Institutional Framework}

Since the Community is an organisation established by states through a treaty, the law applicable to its institutional framework is international law. The legal basis for the institutional framework is found in Article 9 of the Treaty, which stipulates that-

1. There are hereby established as organs of the Community:

(a) the Summit (of Heads of State);

(b) the Council (of Ministers);

(c) the Co-ordination Committee;

(d) Sectoral Committees;

(e) the East African Court of Justice;

(f) the East African Legislative Assembly;

(g) the Secretariat; and

(h) such other organs as may be established by the Summit.

2. The institutions of the Community shall be such bodies, department and services as may be established by the Summit.

3. Upon the entry into force of this Treaty, the East African Development Bank established by the Treaty Amending and Re-enacting the Charter of the East African Development Bank, 1980 and the Lake Victoria Fisheries Organisation established by the Convention (Final Act) for the Establishment of the Lake Victoria Fisheries Organisation, 1994 and surviving institutions of the former East African Community and shall be designated and function as such.

Publishers, 1995 pp. 33-44, and Ray August, et al., International Business Law: Text, Cases and Readings, New Jersey, Pearson Education International, Fifth Edition, 2009, pp. 22-23. Articles 2 and 5 of The Treaty for the Establishment of the East African Community.

24 Articles 5(3)(g), 127-129 of The Treaty for the Establishment of the East African Community. 
4. The organs and institutions of the Community shall perform the functions, and act within the limits of the powers conferred upon them by or under this Treaty. ${ }^{25}$

This Treaty outline does not create a distinct institutional framework, it rather creates four policy-making and administrative organs and sectoral committees. These are i.e. the Summit of Heads of State ("the Summit"), the Council of Ministers ("the Council"), the Co-ordination Committee, the Secretariat and an unspecified number of sectoral committees. This feature could have been intended for the reason that the Treaty is underlain by the preponderance of the Partner States' continuous policy rationalization and harmonization. In such a scenario a more definite category of organs in the policy domain could neither have been provided for with certainty nor foreseen. Apart from the policy organs, the Treaty creates advisory and supervisory organs; the East African Court of Justice ("the Court"), as the judicial arm of the institutional framework; and the East African Legislative Assembly ("the Assembly") as the legislative arm. The Treaty also takes cognizance of institutions.

In a manner corresponding to the Treaty's providing for co-operation in almost all spheres of economic, social, cultural, political and other endeavors for the Partner States' fast, balanced and sustainable development, the basis for the institutional framework leaves room for the creation of such other organs and institutions as the Summit may, in the discharge of its functions deem necessary.

It is important to observe that the Partner States subscribe to an undertaking that "Community organs, institutions and laws shall take precedence over similar national ones on matters pertaining to the implementation of [the] Treaty". ${ }^{26}$ Therefore contrary to what may occur in practice, this undertaking in institution-building pinpoints the supremacy of the Community's organs and institutions in leading the process of integration.

It must be further observed that in the discharge of their respective functions the organs and institutions are bound by the fundamental and operational principles of the Community. Critical among these principles under the Treaty are those that stress a "people-centered and market-driven co-operation" 27 and the application of subsidiarity, ${ }^{28}$ both of which are critical tenets in the

\footnotetext{
25 Article 9 read together with Articles 10-12, 13-16, 17-19, 20-22, 23-47, 48-65, and 66-73.

26 Article 8(4).

27 Article $7(1)(a)$.

28 Article $7(1)(d)$; the principle of subsidiarity emphasizes multi-level participation and the involvement of a wide range of stakeholders in the process on integration.
} 
establishment of a single market and investment area. In the discharge of their respective functions, including during deliberations and decision-making, the organs and institutions are bound by such procedure as they are empowered by the Treaty to determine. ${ }^{29}$ In-built institutional measures such as key ministerial consultations and engagement of the private sector and civil society are supportive of the institutional decision-making process. ${ }^{30}$

\subsection{Analytical Overview of the Main Organs}

The roles of the different organs and institutions seem to mirror the Partner States' intended metamorphosis, outlined in Article 5(2) of the Treaty, from a co-operation arrangement through integration into a political federation most presumably with a single government. Therefore in a manner reflective of the theory of separation of powers the Court is the judicial organ of the Community, ${ }^{31}$ the Council is the main policy organ ${ }^{32}$ and the Assembly is the legislative organ of the Community. ${ }^{33}$

It is important not only to highlight the nature of each organ and institution, by reference to its composition and functions and responsibilities, but also to highlight some fundamental challenges and contradictions facing each organ or institution.

\subsubsection{The East African Legislative Assembly}

The Assembly consists of elected members who are elected by the National Assemblies of the Partner States (elected members); ex-officio members consisting of the Ministers responsible for East African Affairs from each Partner State; the Secretary General; and the Counsel to the Community. ${ }^{34}$ Regarding the elected members Article 50(1) of the Treaty provides that "The

29 Pursuant to Articles 12(5),15(4),19(3),42 and 6o the Summit, the Council, the Co-ordination Committee, the Court and the Assembly have determined their respective rules of procedure.

These measures include regular meetings and consultations among key Ministers responsible for East African Community Affairs, Finance, Justice; Central Bank Governors; the business community under the auspices of the East African Business Council; and the Secretary General's annual forums with identified private sector and civil society organizations.

31 Article 23.

32 Article 14.

33 Article 49(1).

34 Article 48(1). 
National Assembly of each Partner State shall elect, not from among its members, nine members of the Assembly, who shall represent as much as it is feasible, the various political parties represented in the National Assembly, shades of opinion, gender and other special interest groups in that Partner State, in accordance with such procedure as the National Assembly of each Partner State may determine". ${ }^{35}$ The current membership of the Assembly is $5^{2}$, with nine elected members from each of the five Partner States and seven ex-officio members.

The Assembly is the Community's legislative organ. ${ }^{36}$ It is also charged with among other functions, liaising with the national assemblies of the Partner States on matters relating to the Community, ${ }^{37}$ debating and approving the budget of the Community, ${ }^{38}$ considering annual reports of the Community ${ }^{39}$ and discussing all matters pertaining to the Community. ${ }^{40}$ It is, to this extent, expected to be the people's representative on matters relevant to the efficient functioning of the Community.

In order to comply with the Community policy of popular participation in the achievement of its objectives and to reflect the people-centered approach of the Community, the views expressed in the debates of the National Assemblies are taken into account in the Assembly. By the same token, reports on debates of the Assembly are also passed to the National Assemblies for their consideration. ${ }^{41}$

The Assembly's legislative process is undertaken through enactment of Bills initiated by the Council; ${ }^{42}$ or introduced through motions by any Member of the Assembly provided that such a motion relates to the functions of the Community. ${ }^{43}$ However, the Treaty envisages a restriction on the initiation of legislation, namely, the requirement that the Assembly shall not proceed on any Bill, including an amendment to a Bill that makes provision for the imposition of any charge upon any fund of the Community; the payment, issue or withdrawal from any fund or the Community of any moneys not charged thereon or the increase in the amount of any such payment, issue or withdrawal; and the remission of any debt due to the Community. Nor can the

\footnotetext{
$35 \quad$ Article 50(1).

36 Article 49(1).

37 Article 49(2)(a).

38 Article $49(2)(\mathrm{b})$.

39 Article 49(2)(c).

40 Article 49(2)(d).

41 Article 65.

42 Article 14(3)(b).

43 Article 59(1).
} 
Assembly proceed on any motion that makes provision for such purposes. ${ }^{44}$ Article 58 of the Treaty outlines the voting procedure in the Assembly, and stipulates that voting shall be determined "by a majority of the votes of the members present and voting"45 and furthermore that ex-officio members are not entitled to vote. ${ }^{46}$

The Assembly's relatively wide ambit on legislation must be seen against the thrust of the Partner States in the current integration process. Given the fact that the Community has already established a Customs Union, a Common Market and a Monetary Union, the laying of a strong and effective legislative mechanism becomes a sine qua non for both current institutional development and the future constitutional basis of the Community. It is against this background that the Assembly has since inauguration been able to enact basic fundamental laws such as the East African Community Emblems Act 2003, the East African Community Interpretation Act 2003 and the Acts of the Community Act 2003; institutional development laws such as the East African Legislative Assembly (Powers and Privileges) Act 2003, the Summit (Delegation of Powers and Functions) Act 2007, the Inter-University Council for East Africa Act 2008, the East African Legislative Assembly Members Election Act 2011 and the East African Community Parliamentary Institute Act, 2012; and annually enacted Appropriation Acts whose purpose is to make appropriation out of Community's budgets as approved by the Assembly.

Most critically to integration the Assembly has also enacted laws that are supportive of the Partner States' policy rationalisation and harmonization such as the East African Community Customs Management Act 2004, the East African Community Competition Act 2006, the Lake Victoria Transport Act 2007, the East African Community Joint Trade Negotiations Act 2008, the East African Community Standardisation, Quality Assurance, Metrology And Testing Act 2008 and the East African Community Budget Act 2009. ${ }^{47}$ In this category are also the East African Community Civil Aviation Safety and Security Oversight Agency Act 2009, the East African Community Service

\footnotetext{
44 Article 59(2).

45 Article 58(1).

46 Article 58(2).

47 The effectiveness of regional legislation is settled by the provisions of the Treaty (Article 8-and especially paragraphs 4 and 5 thereof) to the effect that Community laws shall take precedence over similar national ones on matters pertaining to the implementation of the Treaty. Therefore once enacted, published and gazetted Community legislation becomes binding on the Partner States.
} 
Commission Act 2010, the East African Community Conflict Management Act 2012, the East African Community Risk Reduction and Management Act 2012, the East African Community Vehicle Axle Load, Act 2013, the East African Community One Stop Border Posts Act 2013, the East African Elimination of Non-Tariff Barriers Act 2014, the East African Community Co-operative Societies Act 2014, the East African Community Integration (Education) Act 2014, the East African Community Electronic Transactions Act 2015, the East African Community Creative and Cultural Industries Act 2015, the East African Community Electronic Transactions Act 2015, the East African Community Persons with Disability Act 2015 and the East African Community Forests Management and Protection Act 2015 which are yet to be assented to by the Heads of State. ${ }^{48}$

The trend in the Assembly's enactment of regional legislation is in quantitative contrast with past regional practice. During the period 1961-1977, the integration process witnessed the enactment of only 35 Acts of the (now defunct) Community. The Assembly's trend is also more advanced and focused when contrasted with that of the Pan-African Parliament and the legislative forums of other regional economic communities like SADC, the Economic Community of West African States (ecowas) and comesa. The SADC Parliamentary Forum is a policy making and deliberative body that approves the SADC budget, makes recommendations to the SADC Summit, considers and makes recommendations on treaties and promotes SADC objectives and programmes. However, the Parliamentary Forum does not legislate and will only serve as a legislative body when in future it assumes, as is anticipated, a regional parliamentary structure. Likewise, the EcowAs Parliament is a forum for ensuring dialogue, consultation and consensus on matters pertaining to the promotion of integration but has no legislative function. Moreover, the Protocol Establishing the Pan-African Parliament does not provide for a legislative role among this AU organ's powers and functions.

However, as much as the legislative momentum is bound to remain on course, a few hurdles will have to be addressed, mainly through EAC intraorgan consultative processes. These hurdles include logistical shortcomings, which prevent the Assembly and relevant Committees from discharging work strictly in conformity with legislative programmes; the Council's slow and

48 By the provisions of Articles 62 and 63, once a Bill has been enacted it is submitted to the Heads of State for assent. 
protracted initiation of Bills; ${ }^{49}$ and Partner States' delays and intransigence in conferring precedence of Community laws over similar national laws.

Moreover, the Assembly has been criticized for exuding a lack of institutional ownership of the Community within the population of East Africa. In this regard, Mukandala has long argued that the Assembly's "set up leaves a lot to be desired" on the basis that "members of the Assembly are elected not directly by the East African electorate, but by the National Assembly of each Partner State. Although those elected are supposed to represent the various political parties and shades of opinion, they still will not be direct representatives of the people. As a result they will not have a constituency in the wider population to whom they will feel obliged to report back." Furthermore, Mukandala notes that "[s]ince their election is a caucus process, it will not involve wide ranging campaigns that can educate people on the Community. This is a lost opportunity for the cause of the Community to be known, its problems and prospects to be debated, appreciated and understood". ${ }^{50}$ However, one may plausibly counter argue that besides the European Parliament there is no directly elected international assembly in the world's integration processes.

Mukandala's views are vindicated by the fact that the current process of electing the members of the Assembly has often given rise to national parliamentary challenge and related litigation. In Prof. Peter Anyang' Nyong'o \& 10 others $v$ Attorney General of Kenya \& 2 Others [Others Intervening], ${ }^{51}$ the Claimants sought an interpretation and application of the Treaty, regarding the validity of the nomination and election of Kenya's nine representatives to the Assembly. The Claimants contended that Kenya's National Assembly did not undertake an election within the meaning of Article $5^{0}$ of the Treaty and that the Election Rules made by Kenya's National Assembly (The Treaty for the Establishment of the East African Community (Election of Members of the Assembly) Rules 2001) for the purpose of conducting the said elections infringed the provisions of Article 50. In support of their claim, evidence was submitted to show that Kenya's National Assembly only approved

49 Bills which have pended action by the Council for long include The Lake Victoria Basin Commission Bill 2008, The East African Privately-Funded Infrastructure Bill 2009, The East African Community Assets Protection Bill 2012 and The East African Community Disaster Preparedness Bill 2013.

Rwekaza Mukandala, 'Political Co-operation' in EAC: Perspectives on Regional Integration and Co-operation in East Africa, EAC Secretariat, Arusha/German Agency for Technical Co-operation (GTZ), 2000, pp. 101-103. 
names submitted by two political parties. The Court held that the bottom line for compliance with Article $5^{0}$ is that the decision to elect is a decision of and by the National Assembly; however the evidence adduced led to only one conclusion, namely that the National Assembly of Kenya neither undertook nor carried out an election within the meaning of Article $5^{\circ}$ of the Treaty.

In Democratic Party and Mukasa Mbidde $v$ Secretary General of the East African Community \& Attorney General of Uganda ${ }^{52}$ the Applicants complained of inaction on the part of the Government of the Republic of Uganda and its Parliament to amend the 2006 Rules of Procedure of Parliament for the election of Uganda's representatives to the Assembly as earlier directed by the Constitutional Court of Uganda. ${ }^{53}$ They further contended that the intention to conduct elections of the Assembly Members under the un-amended 2006 Rules contravened the Treaty in as far as the rules discriminated and limited the freedom and right of the Democratic Party and its members to associate in vying for election as representatives in the Assembly. The Applicant's sought orders to have the Government of the Republic of Uganda and its Parliament conform to the provisions of Article 50 of the Treaty. The Court held that the 2006 Rules did not conform to the Treaty and restrained the Parliament of the Republic of Uganda from conducting the elections unless and until it amended the impugned 2006 Rules to conform to Article 50 of the Treaty.

In both cases, and later in Among A. Anita v The Attorney General of Uganda and Secretary General of the East African Community ${ }^{54}$ and Antony Calist Komu $v$ Attorney General of The United Republic of Tanzania, ${ }^{55}$ the Court upheld the spirit, tenor, language and intent of Article 50(1) of the Treaty. The Court emphasized the requirements of an "election" accommodating all political parties and shades of opinion in actualizing the requirements of that provision, as opposed to a "selection". The moral of these cases is that the institutional framework could do better with strict compliance with the Treaty or, better still, with representation to the Assembly constituted through universal adult suffrage.

\footnotetext{
$52 \quad$ EACJ Ref. No. 6 of 2011.

53 Uganda Constitutional Court Petition No. 28 of 2006: Jacob Oulanyah v Attorney General of the Republic of Uganda.

54 EACJ Ref No. 6 of 2012.

55 EACJ Ref No. 7 of 2012.
} 


\subsubsection{The Summit of Heads of State}

The Summit, which together with the Council and the Secretariat constitutes the executive arm of the Community, consists of the Heads of State or Government of the Partner States. ${ }^{56}$ A "Head of State" is defined to mean "a person designated as such by a Partner State's Constitution"57 and a "Head of Government" means "a person designated as such by a Partner State's Constitution" 58 On the basis of definitions in national Constitutions and interpretation of national laws of the Partner States, both terms refer to Presidents, Vice Presidents and Prime Ministers.

The Summit is principally charged with-

(a) giving general directions and impetus as to the development and achievement of the objectives of the Community; ${ }^{59}$

(b) considering annual progress reports and such other reports submitted to it by the Council as provided for by the Treaty; 60 and

(c) reviewing the state of peace, security and good governance within the Community and the progress achieved towards the establishment of a Political Federation of the Partner States; ${ }^{61}$

The Summit is also responsible for-

(a) appointing Judges of the East African Court of Justice (and designate the President, the Vice President, the Principal Judge and the Deputy Principal Judge); 62

(b) handling membership issues such as admitting foreign countries into the Community; ${ }^{63}$ handling sanctions on, and suspension and expulsion of errant Partner States; ${ }^{64}$

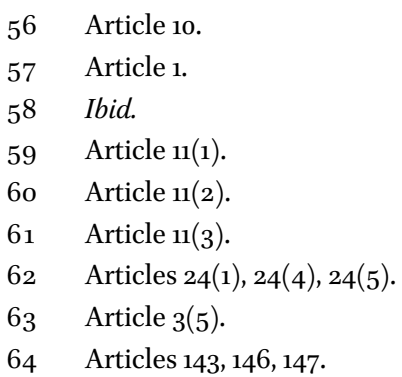


(c) initiating the process towards the establishment of a Political Federation by directing the Council to undertake the process, ${ }^{65}$ and

(d) approving protocols and other annexes to the Treaty. ${ }^{66}$

The Summit's functions are arguably limited to overall policy direction, whereas implementation, operational policy and similar decisions are made by organs subordinate to the Summit. It is also important to note that some of the functions of the Summit may, through an Act of the Community, be delegated to the Council or the Secretary General. ${ }^{67}$ This position represents a volte-face from the defunct East African Community whose institutional arrangement reflected a deep seated involvement of the East African Authority which similarly was comprised of Heads of State and whose failure to meet and make decisions has often been cited as one of the reasons for the collapse of that earlier integration arrangement. ${ }^{68}$

The functioning of the Summit also observes the principle of the separation of powers. Firstly, the separation of powers is emphasized by the fact that in giving general directions and impetus as to the development and achievement of the objectives of the Community, the Summit may be said to operate through the Council from whom it receives reports for consideration. ${ }^{69}$ Secondly, there is no operational linkage with the Court or with the Assembly. The requirement that each of the members of the Summit assents to Bills enacted by the Assembly does not create such a linkage. Reference to "legislative powers" in the provision of the Treaty for an Act on delegation of the powers of the Summit ${ }^{70}$ has sometimes been misconstrued to suggest that the Summit may encroach on the Assembly's domain. However, this reference may have been framed only with regard to assent to Bills. It too, therefore, cannot create such a linkage.

\footnotetext{
65 Article 123(6).

66 Article 151(2).

67 Articles $11(5), 11(6), 11(7)$. It is the actualization of these provisions that gave rise to the enactment of The Summit (Delegation of Powers and Functions) Act 2007.

68 Sam G. Nahamya, Regional Economic Disintegration: Tensions, Conflicts and Causes-the Case of the East African Community, Fort Collins, Colorado State University, 1980. See also Juma Volter Mwapachu, Challenging The Frontiers of African Integration: The Dynamics of Policies, Politics and Transformation in the East African Community, Dar es Salaam, E\&D Vision Publishing Limited, 2012 p. 55.

69 Article 1.

70 Article $11(6)$.
} 
The role of the Summit has been subject to judicial scrutiny in The East Africa Law Society \& 5 Others $v$ the Attorney General of the Republic of Kenya $\& 4$ Others. ${ }^{71}$ The Applicants challenged the legality of an amendment to the Treaty which had been adopted by the Summit and which, among other things, created new grounds upon which a Judge of the Court could be removed to include situations where that Judge is removed from that office for misconduct or due to inability to perform the functions of the office for any reason; where the Judge resigns from that office following allegation of misconduct or of inability to perform the functions of the office for any reason; or where a Judge is subject to investigation by a tribunal or other relevant authority of a Partner State with a view to his or her removal from an office referred. The amendments also empowered the Summit to suspend a Judge from the exercise of the functions of his or her office on those grounds. It was contended by some people that the amendment was motivated by the desire to 'punish' judges of the Court for their decision in Prof. Peter Anyang' Nyong'o \& 10 Others $v$ The Attorney General of Kenya \& 5 Others which had gone against, and allegedly "embarrassed" a Partner State. It was further argued that the amendment was in violation of the Treaty provisions in so far as it did not comply with the procedures governing amendments to the Treaty-including consultations. A key issue was whether failure to carry out wide consultations on the proposals for the amendments to the Treaty constitutes an infringement of the Treaty.

The Court, while rightly leaving the amendments intact, held inter alia that-

(a) there was a deliberate attempt in the formulation of the Treaty to ensure that East Africans, for whose benefit the Community was established, participate in protecting the integrity of the Treaty;

(b) the principle of people-centered cooperation is also applicable to the Treaty amendment process. Until more elaborate modalities are evolved as the Community continues to grow, the resolve to allow participation of the private sector and civil society recited in the preamble, and the objective to enhance and strengthen partnerships with the private sector and civil society enunciated in Article 5(3) $(\mathrm{g})$, provide adequate guidelines; and 
(c) the introduction of automatic removal and suspension of judges of the Court on grounds raised or established in any one Partner State, and applicable to only those in judicial or public office, may endanger the integrity of the Court as a regional court.

The decision may generally reflect dictates of good governance. However, the Court also decided that "the correct construction of Article 150(5) of the Treaty must be that the provision directs the Secretary General to submit proposed amendments and comments received from Partner States to the Summit not later than the expiry of a period of go days. There is no express or implied requirement for the Partner States to carry out any consultations, nor is the Secretary General required to hold proposed amendments and comments received from Partner States until expiration of that period".72 Indeed some scholars like Kasaija have asserted that the application was in effect dismissed and the amendments themselves were not bad per se. ${ }^{73}$

\subsubsection{The Council of Ministers}

The Council consists of the Ministers responsible for East African Community Affairs, the Attorney General and such other Ministers as each Partner State may determine. ${ }^{74}$ A "Minister" in relation to a Partner State means "a person appointed as a Minister of the Government of that Partner State and any other person, however entitled, who, in accordance with any law of that Partner State, acts as or performs the functions of a Minister in that State".75 The term "Attorney General" means "the Attorney General of a Partner State". ${ }^{76}$

The Council is the policy organ in as far as implementation of the Treaty provisions and integration programmes are concerned. ${ }^{77}$ The Treaty does not define the term "policy". From an economic and political point of view, "policy" should mean a set of principles to broadly guide decisions and achieve rational outcomes in a given process. With regard to the Community, policy

\footnotetext{
$72 \quad$ Ibid., p. 25.

73 Philip Kasaija, The State of Constitutionalism in East Africa: The Role of the East African Community (EAC)-2007 In Constitutionalism in East Africa Ed by Wanza Kioko, Kampala Foundation Publishers, 2009 pp. 16-17.

74 Article 13.

75 Article 1.

$76 \quad$ Ibid.

77 Op. cit., footnote 31 .
} 
should relate to the agreed approach towards the realization of the primary or strategic objectives of the Community as provided under the Treaty.

This key function of the Council is vindicated by the fact that the Treaty bestows on the Council-

(a) advisory roles vis-à-vis all other organs and institutions e.g. to the Summit with regard to the salaries and other terms and conditions of service of the Judges of the Court and Members of the Assembly; the appointment of Deputy Secretaries General of the Community; and expansion of country membership of the Community; ${ }^{78}$

(b) binding supervisory roles in the sense that "Subject to the provisions of the Treaty, the regulations, directives and decisions of the Council taken or given in pursuance of the provisions of this Treaty shall be binding on the Partner States, on all organs and institutions of the Community other than the Summit, the Court and the Assembly within their jurisdictions, and on those to whom they may under this Treaty be addressed.";79 powers to establish institutions such as those necessary to administer the Common Market and those like specific sectoral councils and sectoral committees; ${ }^{80}$ and

(c) power to establish institutions such as those necessary to administer the Common Market and those like specific sectoral councils and sectoral committees; ${ }^{81}$ and

(d) power to consider and approve policy rationalization and harmonization undertakings in the various areas of co-operation. ${ }^{82}$

Apart from assisting the Summit in the performance of its functions (including the implementation of the decisions and directives of the Summit), and the said supervisory powers the Council is required to-

$78 \quad$ Articles 3(6), 25(5), 51(2) and 68(2).

79 Article 16.

8o The Council may establish sectoral councils (Article 14(3)(i)), creates sectoral committees and may establish institutions for the administration of the Common Market (Article 76(3)).

81 The Council may establish sectoral councils (Article 14(3)(i)), creates sectoral committees and may establish institutions for the administration of the Common Market (Article $76(3)$ ).

82 This power applies to progress in all areas of co-operation provided in Chapters Eleven to Twenty Seven of the Treaty. 
(a) promote, monitor and keep under constant review the efficient functioning and development of the Community and in this regard, to consider measures that should be taken by the Partner States in promoting the attainment of the objectives of the Community; ${ }^{83}$

(b) initiate and submit Bills to the Legislative Assembly; ${ }^{84}$

(c) consider the Budget of the Community (once prepared by the Secretary General); 85

(d) make staff and financial rules and regulations; ${ }^{86}$ and

(e) submit annual progress reports to the Summit. ${ }^{87}$

For the purpose of ensuring administrative support to the discharge of its functions the Council is required to engage the Counsel to the Community, the Registrar of the Court, the Clerk of the Assembly, heads of institutions and other members of staff of the Community in employment. ${ }^{88}$

The current Council can be contrasted to its predecessor, which existed under the framework of the defunct EAC. Notably, in comparison to the Ministers of the Community, the current Council is significantly less powerful. ${ }^{89}$ This contraction of powers is important as the powers bestowed on the Council are crucial for ensuring that decisions are taken on time and that implementation is effectively monitored. For example, directives and regulations are the main conduits through which the objectives of the Customs Union, the Common Market and the Monetary Union are expected to be achieved. ${ }^{90}$

The Council's policy symbiosis with the Assembly is borne out by the latter's consideration and enactment into law of the former's Bills. The Council's

\footnotetext{
83 Articles 14(2), 14(3)(f).

84 Article 14(3)(b).

85 Article 14(3)(e) read together with Article 132(2).

86 Article 14(3)(g).

87 Article 14(3)(h).

88 Articles 45, 49(2)(f), 69 and 70.

89 Juma Volter Mwapachu, Challenging The Frontiers of African Integration: The Dynamics of Policies, Politics and Transformation in the East African Community, Dar es Salaam, E\&D Vision Publishing Limited, 2012 p. 56. See also op. cit., footnote 3.

9o See for example Article 39(1)(c) of The Protocol on the Establishment of the East African Community Customs Union, Articles 10(4), 12(3), 19(6), 23(3), 36(2), 41(4), 42(3), 42(5), 43(5), 44(3), 47(2) and 51 of The Protocol on the Establishment of the East African Community Common Market and Article 27 of The Protocol on the Establishment of the East African Community Monetary Union.
} 
dependence on the Court is founded on the provision that "The Council may request advisory opinions from the Court." ${ }^{91}$

The Council's discharge of functions has resulted in the development of several programmes and projects in different areas of co-operation as outlined by the Treaty and using development strategies as bases. The Council's impact on the development of the institutional framework is borne out by the fact that it is the Council that proposes the establishment of new organs, institutions and offices. It is also the Council that is empowered to grant observer status in the Community to inter-governmental and civil society organisations. ${ }^{92}$

Action by the Council was first subject to judicial scrutiny in Calist Mwatela and 2 Others $v$ East African Community ${ }^{93}$ where the Court also underlined the separation of powers within the Community's institutional framework. The Applicants challenged the validity of the meeting of the Sectoral Council on Legal and Judicial Affairs held between the 13th and 16th of September 2005. They contended that a decision reached at that meeting to the effect that three Bills originally introduced into the Assembly by way of private member motions but which had been taken over by the Council should be withdrawn from the Assembly ran contrary to the Treaty and should be rendered null and void. The Court decided-

(a) the Treaty has not bestowed any power on the Council to take over Bills without observance of the Assembly Rules and the only lawful way of withdrawing Bills which have become property of the Assembly, as the three Bills had become, is under Rule 34 of the Assembly Rules which provides for a Motion to be introduced in the Assembly for that purpose; and

(b) in light of Articles 14 and 16 of the Treaty, the decisions of the Council have no place in areas of jurisdiction of the Summit, Court and the Assembly.

\subsubsection{The Secretariat}

The Secretariat, headed by the Secretary General of the Community, is responsible for, among other functions-

\footnotetext{
$91 \quad$ Article 36.

92 Under different protocols; Article 3(5)(b).

93 EACJ Ref No. 1 of 2005 .
} 
(a) initiating, receiving and submitting recommendations to the Council, and forwarding of Bills to the Assembly;

(b) the initiation of studies and research related to, and the implementation of, programmes for the most appropriate, expeditious and efficient ways of achieving the objectives of the Community;

(c) the strategic planning, management and monitoring of programmes for the development of the Community;

(d) the undertaking either on its own initiative or otherwise, of such investigations, collection of information, or verification of matters relating to any matter affecting the Community that appears to it to merit examination;

(e) the co-ordination and harmonization of the policies and strategies relating to the development of the Community;

$(f)$ the general promotion and dissemination of information on the Community to the stakeholders, the general public and the international community;

(g) the submission of reports on the activities of the Community to the Council;

(h) the general administration and financial management of the Community;

(i) the mobilization of funds from development partners and other sources for the implementation of projects of the Community;

(j) the submission of the budget of the Community to the Council for consideration;

(k) preparing draft agenda for the meetings of the organs of the Community other than the Court and the Assembly;

(l) the implementation of the decisions of the Summit and the Council;

( $m$ ) the organization and the keeping of records of meetings of the institutions of the Community other than those of the Court and the Assembly;

(n) the custody of the property of the Community; and

(o) the establishment of practical working relations with the Court and the Assembly. ${ }^{94}$

The key role played by the Secretariat in the Community's institutional framework received judicial recognition in Timothy Alvin Kahoho v Secretary

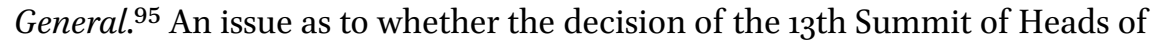

94 Article 9o(1).

95 EACJ Ref No. 1 of 2012. 
State Decision to mandate the Secretariat to propose an action plan on, and a draft model of the structure of the East African Federation was in contravention of the operational principles under the Treaty and the Partner States' undertaking to implement the Treaty. In deciding the issue in the negative, and recognizing that the Secretariat is the only organ created to steer the ship of integration by implementing decisions of all the other Organs, the Court stated inter alia that: "While addressing this issue, it behooves us to address in a few words the critical role that the Secretariat plays in the affairs of the Community, generally." Prof. Sam Turyamuhika writes as follows: ${ }^{96}$

"The current EAC Secetariat has been typified as powerless, meetings and workshop organizer, minute taker etc." We take a different view of that harsh and unfair judgment. The EAC Secretariat is the fulcrum on which the wheels of integration rotate. The Summit, the Council of Ministers, the Co-ordination Committee and Sectoral Committees are all part-time and meet only as often as their functions require. Yet, the Secretariat slogs, day in, day out, to ensure that the ship of integration remains afloat. The Community, in our view, is like a giant ship owned by shareholders (the people of East Africa); the Summit is like a Board of Directors and the Council, is like the Management. The Captain is the Secretary-General and the crew are the staff in the Community. To call the Captain and crew, useless, and denigrate their role in keeping any ship on the high seas on course, is to say that the shareholders or the Board of Directors can single-handedly and without any input from those that physically man the ship, sail that ship from a distance. The Summit represents the owners of the ship, and its duty is to decide where the ship goes and should always act in the best interests of the shareholders. The Summit thus meets periodically to assess progress and regularly inform the shareholders of the profits (benefits) from the operations of the ship. The Council, Co-ordination and Sectoral Committees are the Summit's agents in overseeing progress aforesaid. Without the Captain and crew, the ship can barely survive the storms and other perils that are prevalent in high seas including attacks by pirates. We digressed to make the point that, our reading and understanding of Articles 11, 14, 18, 21 and 71 of the Treaty, which create the functions of the Organs of the Community, is that the Secretariat is the only Organ created by Article 9 of the Treaty to steer the ship of integration by implementing decisions of all the other Organs and its crucial role thereby ought to be recognized and supported".97

\footnotetext{
96 Sam Turyamuhika, In The Drive Towards Political Integration in East Africa, Ed by Isabelle Waffubwa and Joseph Clifford Birungi, p. 173. 
The main challenge facing the Secretariat relates to it responsibility concerning "the implementation of the decisions of the Summit and the Council". This is regarded as challenging because the Secretariat lacks the administrative mechanism and resources to police the Partner States in their general undertaking as to the implementation of the Treaty, certainly when compared for example to the European Commission. ${ }^{98}$ Indeed Mwapachu aptly observes that the lack of executive authority is among the many challenges facing the Secretariat as "[w] ith no tangible executive authority whereby every act of the Community is subjected to sovereign interests and concerns of the Partner States, the movement towards the realization of a robust EAC integration not to speak of achieving the EAC goal is clearly slow tracked."99 However, the responsibility for the co-ordination and harmonization of the policies and strategies relating to the development of the Community ${ }^{100}$ should be a strength in the desired role for the Secretariat to steer a supranational organization.

\subsubsection{The East African Court of Justice}

The Court is the "judicial body" of the Community. ${ }^{101}$ The role of the Court, which has both a First Instance Division and an Appellate Division, is to ensure the adherence to law in the interpretation and application of the Treaty. ${ }^{102}$ The Court is composed of a maximum of fifteen Judges: a maximum of ten appointed to the First Instance Division and maximum of five appointed to the Appellate Division. ${ }^{103}$ Its Judges are appointed "by the Summit from among persons recommended by the Partner States who are of proven integrity, impartiality and independence and who fulfil the conditions required in their own countries for the holding of such high judicial office, or who are jurists of recognised competence in their respective Partner States." 104 This appointment is subject to the restriction that no more than two Judges of the First Instance, or one Judge of the Appellate Division shall be appointed on the recommendation of the same Partner State. ${ }^{105}$

For purposes of adjudicating between legal and natural persons the Court-

98 See in this regard also the powers of the European Commission as discussed in EU chapter 2.

99 Op. cit., footnote 9o, pp. 41-42.

100 Article $71(1)(\mathrm{e})$.

101 Article 23.

102 Articles 23 and 27.

103 Article 24(2).

104 Article 24.

105 Article 24(1) (a)-(b). 
(a) is competent to accept and adjudicate upon all matters pursuant to the Treaty for purposes of determining the legality of any act, regulation, direction, decision, action or matter; to this extent the Court's jurisdiction also covers references by the Partner States, references by the Secretary General, Community Staff disputes, matters arising out of arbitral proceedings, ${ }^{106}$ and

(b) may also be called upon to give advisory opinions regarding questions of law arising from the provisions of the Treaty. ${ }^{107}$

Initially the Court's jurisdiction was limited to ensuring adherence to law in the interpretation and application of the Treaty. ${ }^{108}$ However, for the purpose of ensuring conflict resolution and confidence building in the region it has always been envisaged by the Treaty that the Court shall have such other original, appellate, human rights and other jurisdiction as should be determined by the Council at a suitable date. In 2015, the Court's jurisdiction was extended to cover trade and commercial disputes and disputes arising out of the implementation of the Protocol on the Establishment of the East African Monetary Union.

Notwithstanding its broad jurisdiction, the Court is not designed to deny national courts their respective jurisdictions in accordance with the respective municipal laws. ${ }^{109}$ In this regard, the Court can handle cases stated for preliminary rulings on matters of the Treaty. ${ }^{110}$

To date the Court should be credited with having generated not only regional jurisprudence but also public confidence in the integration process. It is important for the public to know that the Partner States and the organs and institutions of the Community cannot avail of impunity for any wrongdoing under the Treaty. The Court's decisions in Prof. Peter Anyang' Nyong'o $\& 10$ others $v$ Attorney General of Kenya \& 2 Others [Others Intervening] ${ }^{111}$ and Democratic Party and Mukasa Mbidde $v$ Secretary General of the East African Community \& Attorney General of Uganda ${ }^{112}$ are of particular significance to institutional development as they are examples of the Court upholding the rule of law within the Community's institutional framework.

\footnotetext{
106 Articles 27, 28, 29, 30, 31 and 32.

107 Op. cit., footnote 89.

108 Op. cit., footnote 99.

109 Article 33.

110 Article 34.

111 Op. cit., footnote 51.

112 Op. cit., footnote 52.
} 
The Court's decisions in East Africa Law Society $v$ Secretary General East Africa Law Society ${ }^{113}$ and East African Center for Trade Policy and Law $v$ Secretary General ${ }^{114}$ are also worth highlighting as far as the EAC institutional development is concerned. In both cases Article 24 (1) (e) of the Protocol Establishing the East African Community Customs Union (which establishes an East African Trade Remedies Committee to handle matters pertaining inter alia to rules of origin, anti-dumping, subsidies and countervailing measures and safeguard measures), and Article 54(2) of the Protocol for the Establishment of the East Africa Community Common Market (which empowers competent judicial, administrative or legislative authority or any other competent authority to handle disputes arising out of the implementation of the Protocol) were in issue. The provisions were impugned for allegedly being inconsistent with Articles 27(1) and 38(1) and (2) and by establishing "parallel adjudicatory bodies" or allowing national courts and other institutions to handle Customs and Common Market disputes, infringing on the jurisdiction of the East African Court of Justice. The Court held in both cases that-

(a) the dispute settlement mechanisms created under the Customs Union and Common Market Protocols do not exclude, oust or infringe upon the interpretative jurisdiction of the Court; but are merely alternative dispute resolution mechanisms intended for the speedy and effective resolution of trade disputes by experts in technical and specialized areas; any submission that this Court lacks jurisdiction over disputes arising out of the interpretation and application and implementation of the Protocols cannot be sustained;

(b) the impugned provisions of both Protocols are not in contravention of or in contradiction with the relevant provisions of the Treaty; and

(c) the establishment of the Committee on Trade Remedies or the conferring of jurisdiction upon national judicial, administrative or legislative mechanisms would not prevent Partner States from complying with Article 8 (1) (a) (which imposes on each individual Partner State an obligation to ensure that objectives of the Community are kept in mind during the planning and allocation of resources processes) and Article 8 (1) (c) (which contains a prohibition on

\footnotetext{
113 EACJ Ref. No. 1 of 2011.
}

114 EACJ Ref. No. 9 of 2012. 
each individual Partner State to take any measure that is likely to jeopardize the achievement of the Treaty). ${ }^{115}$

The jurisprudence of the Court further demonstrates the Court's adherence to the separation of powers. For instance, in Mbidde Foundation Limited and Rt Hon Margaret Zziwa $v$ Secretary General of the East African Community and The Attorney General of Uganda ${ }^{116}$ the Court, in declining to intervene in the Assembly's process of impeachment of Rt Hon Margaret Zziwa as Speaker of the Assembly as sought by the Applicants, upheld the rule on separation of powers.

The Court remains faced with challenges such as difficulties associated with the enforcement of judgments and rulings as provided for under Articles 38 and 39 of the Treaty; the need for a balance between adjudicating in the primary interests of litigants and the strict application of stringent provisions of the Treaty such as that on limitation of actions as provided under Article 3o(2) of the Treaty; and the possibility of the Judges, who pursuant to Article 140(4) of the Treaty (until the Court is declared fully operational), find themselves working under circumstances of "double allegiance" because they remain judicial officers in the Partner States' respective judiciaries and can only serve the Court in circuits sanctioned upon permission by the Chief Justices taking into account the business at their respective national Courts.

The Court can be strengthened through measures including the determination that the Court is fully operational as this would enable the Judges to serve on a permanent rather than ad hoc basis; and consideration of possible amendments to the Treaty in relevant areas of concern such as the need to establish a nexus between the trade dispute mechanisms established under the Customs Union and the Common Market Protocols and the Court as the judicial arm of the Community charged with the interpretation of the Treaty. There is also a need for continued discourse on the possibility of future inclusion of crimes against humanity (as an aspect of criminal jurisdiction, and an offshoot of universal human rights jurisdiction) within the Court's jurisdiction. This is informed by the fact that some of the divisions in the Partner States' High Courts handle crimes similar to those established under the Rome

\footnotetext{
115 See in this regard also the case law of the European Court of Justice on its exclusive jurisdiction as set out in EU chapter 2, for instance in Opinion 2/13 on the accession of the EU to the ECHR.

116 EACJ Applications Nos. 5 \& 10 of 2014.
} 
Statute of the International Criminal Court and the fact that only four of the Partner States are party to that Statute. ${ }^{117}$

\subsection{Analytical Overview of Other Institutions and Bodies}

\subsubsection{The Co-ordination Committee}

The Co-ordination Committee consists of "Permanent Secretaries responsible for East African Community Affairs and such other Permanent Secretaries as each Partner State may determine".118 Principally, the Co-ordination Committee is charged with submitting reports and recommendations to the Council either on its own initiative or upon request by the Council on the implementation of the Treaty. The Co-ordination Committee is responsible for co-ordinating the activities of the Sectoral Committees and to that extent it is an organ to which Sectoral Committees are answerable. ${ }^{119}$

Furthermore, the Co-ordination Committee is charged with implementing "the decisions of the Council as the Council may direct".120 It is submitted that this seems to be superfluous as the implementation of the integration agenda is an obligation and undertaking of the Partner States. Moreover, even if this was not the case, the Co-ordination Committee, which only makes recommendations as opposed to decisions, would not be the apt organ to implement the decisions of the Council.

\subsubsection{Sectoral Committees}

The Sectoral Committees are established by the Council on the recommendation of the Co-ordination Committee. ${ }^{121}$ They are primarily responsible for the preparation of comprehensive implementation programmes and setting out priorities for different sectors of co-operation. They are also charged with monitoring and keeping under constant review the implementation of the Community's sectoral programmes. ${ }^{122}$

\footnotetext{
117 The Republic of Rwanda is not party to the Rome Statute.

118 Article 17 .

119 Article 18. Compare in this regard also the role of COREPER in the EU, as discussed in EU chapter 2 .

120 Ibid.

121 Article 20.

122 Article 21.
} 


\subsubsection{Institutions of the Community}

The institutions of the Community so far established by the Summit are: the East African Civil Aviation Safety and Security Oversight Agency, the East African Health Research Council, the East African Kiswahili Commission, the East African Science and Technology Commission, the Inter-University Council for East Africa and the Lake Victoria Basin Commission. The surviving institutions of the former East African Community, which are now deemed to be institutions of the new Community, are the East African Development Bank and the Lake Victoria Fisheries Organization. ${ }^{123}$

The development of the institutions has been necessitated by the Partner States' imperative to articulate the scope and necessary institutional mechanism for achieving objectives in different areas of co-operation. Accordingly, the establishment of the East African Civil Aviation Safety and Security Oversight Agency is a consequence of the Partner States' co-operation in civil aviation and civil air transport; the establishment of the East African Health Research Council, the East African Science and Technology Commission may be attributed to expanded co-operation in health, science and technology; the establishment of the Inter-University Council for East Africa, the Lake Victoria Basin Commission and the East African Kiswahili Commission was necessitated by the Partner States' respective undertakings to revive an erstwhile Inter-University Council, to establish an apex body for the management of Lake Victoria and the development of Kiswahili as a lingua franca of the Community.

\subsubsection{East African Civil Aviation Safety and Security Oversight Agency (CASSOA)}

The East African Civil Aviation Safety and Security Oversight Agency (CASSOA), like the preceding East African Directorate of Civil Aviation, ${ }^{124}$ is required

123 The definition of "surviving institutions" in the Treaty's Article 1 also includes the East African Civil Aviation Academy, Soroti and the East African School of Librarianship. However the Community has not repossessed these two as was anticipated. According to Article 14.01 of The East African Community Mediation Agreement 1984, Kenya, Tanzania and Uganda agreed that "the Soroti Civil Flying School, the East African Development Bank, the East African Inter-University Committee, the Eastern and Southern African Management Institute, and the East African Community Library Services shall continue to function as joint East African institutions or common services, as the case may be, and agree to make appropriate arrangements for the financing and operation thereof".

124 Within the institutional framework of the defunct Community, the Directorate of Civil Aviation was charged with among other roles the provision of technical services for aviation safety, initiation of aviation legislation, pilot training. 
"to promote the safe, secure and efficient use and development of civil aviation within and outside the Partner States; assist the Partner States in meeting their safety and security oversight obligations and responsibilities under the Convention on International Civil Aviation 1944; and provide the Partner States with an appropriate forum and structure to discuss, plan and implement common measures for safe and orderly development of international civil aviation". ${ }^{125}$

Prominent among the functions of the CASSOA are to "strengthen the Partner States' institutional framework for aviation safety and security; coordinate the Partner States' civil aviation safety and security oversight activities; foster the Partner States' timely implementation of International Civil Aviation Organisation regional air navigation requirements plans, standards and practices; evaluate the status of aviation safety and security in the Partner States; and facilitate the Partner States' sharing of technical expertise and facilities in civil aviation." 126

\subsubsection{East African Development Bank (EADB)}

The East African Development Bank (ЕАDB), which was established in 1967 under the Treaty for East African Cooperation is a development finance institution with the objective of promoting and strengthening socio-economic development and regional integration. ${ }^{127}$ Following the breakup of the defunct East African Community in 1977, the EADB was re-established under its own Treaty: the Treaty Amending and Re-enacting the Charter of the East African Development Bank (1980). The member countries are currently Kenya, Tanzania, Rwanda and Uganda. The Republic of Burundi has also applied for membership.

To the extent that the ЕАDв plays a threefold role of lender, adviser and development partner, it may be regarded as a catalyst in the pursuit of the Partner States' undertaking to "co-operate in financing projects jointly in each other's territory, especially those that facilitate integration within the Community." 128

\footnotetext{
125 Protocol on the Establishment of the East African Community Civil Aviation Safety and Security Oversight Agency, Article 4.

126 Ibid., Article 5.

127 Article 1 of The Treaty Amending and Re-enacting the Charter of the East African Development Bank, 1980.

128 Ibid.; read together with Articles 8-18.
} 


\subsubsection{East African Health Research Commission}

The East African Health Research Commission (EAHRC) has a vision for "high quality health research for purposes of improvement of the health and well-being of the peoples of the Community." 129 The EAHRC aims at "improving the health of the citizens in the Partner States through capacity building and poverty reduction by promoting, co-ordinating and formulating policies for effective utilization of results from health research" ${ }^{130}$

Specifically the EAHRC seeks to, among other functions "strengthen health research collaboration and co-ordination; promote the application of knowledge obtained from health research; promote the development of human resource capacities in health research; promote exchange and dissemination of health research information; and facilitate the creation of health research databases; liaise with national, regional and international health institutions; and develop quality assurance processes and address common intellectual property rights relevant to health in the Partner States"131

\subsubsection{East African Kiswahili Commission}

The East African Kiswahili Commission has a vision "to be the leading body in the promotion and coordination of the development and usage of Kiswahili for regional unity and sustainable socio-economic development in Partner States"132

The Commission mainly aims at "strengthening national, regional and international communication through the use of Kiswahili in East Africa and beyond; developing Kiswahili as a regional language expressing and conveying African values with respect to issues of gender equity, human rights and democracy; encouraging collaboration in regional research and assisting the Partner States to develop centers of advanced study and research in Kiswahili; assisting the Partner States to offer quality education for the production of Kiswahili teachers and communicators in all sectors of society; promoting curriculum reform to equip citizens with the Kiswahili literary and linguistic skills and knowledge which meet the needs of the East African society and conform to the development plans of East Africa; developing quality assurance processes, through harmonization of Kiswahili language education programmes, curricula and certification,

129 Protocol on the Establishment of the East African Health Research Commission, Articles 2, 3 .

130 Ibid., Article 3.

131 Ibid., Article 7.

132 Protocol on the Establishment of the East African Kiswahili Commission, Articles 2, 3, 5 and 6. 
in order to ensure that teaching and research in Kiswahili achieve and maintain acceptable standards; and assisting governments and other appropriate bodies and authorities with the development of strategies for adequate investment in the promotion of Kiswahili in East Africa and beyond".133

For the purposes of achieving these objectives, the Commission plays an advisory, collaborative and co-ordination role. ${ }^{34}$

\subsubsection{East African Science and Technology Commission (EASTECO)}

The East African Science and Technology Commission (EASTECO) is charged with promoting and co-ordinating the development, management and application of science and technology in the Partner States. ${ }^{135}$ EASTECo is therefore expected to "co-ordinate and facilitate the activities of the Partner States and national science and technology institutions in promoting the development and application of science, technology and innovation in all aspects including policy development, administrative issues, resource mobilization and utilization, research and development, product and project development".136

\subsubsection{Inter-University Council for East Africa (IUCEA)}

The mission of The Inter-University Council for East Africa (IUECA) is "to encourage and develop mutually beneficial collaboration between Member Universities, and between them and Governments and other organizations".137

IUECA is therefore charged mainly with "strengthening regional communication among the universities; initiating, assisting and encouraging the development of East African higher institutions of learning; encouraging collaboration in regional research; mobilizing universities to offer quality education; promoting curriculum reform in order to equip graduates with the skills and knowledge that meet the needs of employers and conform to the development plans of East Africa; and developing quality assurance processes in order to ensure that teaching and research achieve and maintain international standards"138

\footnotetext{
133 Ibid., Article 7.

134 Ibid., Article 8.

135 Protocol on the Establishment of the East African Science and Technology Commission, Article 5.

136 Ibid., Article 6.

137 The Inter-University Council for East Africa Act 2008, Sections 3 and 4.

138 Ibid., Section 6.
} 


\subsubsection{Lake Victoria Basin Commission (LVBC)}

The Lake Victoria Basin Commission (LVBC) was established for the management of the Lake Victoria Basin. The LVBC is responsible for coordinating the sustainable development agenda of the Lake Victoria Basin. ${ }^{139}$

The broad functions of the institution are "to promote, facilitate and coordinate activities of different actors towards sustainable development and poverty eradication of the Lake Victoria Basin" through the harmonization of policies, laws, regulations and standards; the promotion of stakeholders' participation in the sustainable development of natural resources; promotion of capacity building and institutional development; promotion of security and safety on Lake Victoria; promotion of research and development; monitoring, evaluation and compliance with policies and agreed upon actions; preparation and harmonization of the Partner States' negotiating positions against any other state on matters concerning the Lake Victoria Basin; consideration of reports from the Partner States' institutions on their activities relating to the management of the Basin under The Lake Victoria Basin Commission Protocol; and initiation and promotion of programmes that target poverty eradication".140

\subsubsection{Lake Victoria Fisheries Organisation (LVFO)}

The primary functions of the Lake Victoria Fisheries Organisation (LVFO), established by the Convention (Final Act) for the Establishment of the Lake Victoria Fisheries Organisation, 1994, are to build cooperation among the Member States, to harmonize domestic laws and regulations for the sustainable use of the living resources of Lake Victoria, and to develop and adopt conservation and management measures. ${ }^{141}$

LVFO is charged with "promoting the proper management and the optimum utilization of the fisheries and other resources of Lake Victoria; enhancing the capacity building of existing institutions and developing additional relevant institutions, in cooperation with existing institutions and other international, regional and non-governmental organizations; creating a forum for discussion regarding environmental and water quality initiatives affecting the Basin and maintaining a liaison with existing bodies and programs; conducting research regarding water quality in Lake Victoria; encouraging, recommending, coordinating and, as appropriate, undertaking relevant training and extension activities concerning the fisheries; considering and advising on the effects of the introduction of

\footnotetext{
139 Protocol For the Sustainable Development of Lake Victoria Basin, Articles 33-42; read together with Articles 3-32.

140 Ibid.

141 The Convention (Final Act) for the Establishment of the Lake Victoria Fisheries Organisation, 1994, Article II.
} 
non-indigenous aquatic animals or plants into Lake Victoria or its tributaries and adopting measures related to the introduction, monitoring, control or elimination of such animals or plants; serving as a clearing house and databank for information on Lake Victoria's fisheries and promoting the dissemination of information; adopting budgets, seeking funding, formulating financial management plans and allocating funds for the Organisation's activities in furthering the purposes of the Convention (Final Act) for the Establishment of the Lake Victoria Fisheries Organisation, 1994." ${ }^{142}$

The institutions that are already in place have several achievements to their name, for instance, CASSOA's harmonization of regional aviation safety and security regulations and technical guidance materials; EADB's growing range of financial services in real and property development, infrastructure development, trade finance, capital markets development, business advisory services etc.; IUCEA's strengthening of higher education quality assurance processes and enhancement of regional research management; and LVBC's Lake Victoria Water and Sanitation Project, Mt Elgon Regional Ecosystem Conservation Programme and the Mara Basin Project.

Establishment and projection aside, the nature and structure of the new institutions raises a few queries. Whereas the LVBC, the EAHRC, EASTECO and the East African Kiswahili Commission are supposed to be legal personalities, their establishment has not, contrary to policy, been based on an Act of the Community but on protocols i.e. international agreements. In some cases the process of establishing an institution on a strong legal and statutory basis has been protracted. For instance, the East African Civil Aviation Safety and Security Oversight Agency Bill has never been fully assented to, even though it was enacted in 2009. Furthermore, although these institutions are required to report to the Council, the procedure for this is not harmonized because some of the institutions are also required as legal entities to report to their own corporate boards, as is the case with the EADB. They may also be required to report to Ministerial councils, which are arguably external in composition to the Community's institutional framework, as is the case with the LVFo. Furthermore, because there is no common basis for the establishment of the institutions the Secretary General's negotiations with the Partner States for the grant of privileges and immunities to them and their staff is not as accordant as it should be. There is therefore need to establish a policy framework indicating the exact relationship of the organs and institutions inter se. The moot point is whether the institutions are meant to be specialized agencies with a distinct legal personality of their own or subsidiary organs only exercising delegated powers.

142 Ibid. 


\subsubsection{Other Bodies, Departments and Services}

Other bodies, departments and services within the framework should include-

(a) The East African Community Trade Remedies Committee established to handle disputes and investigate on matters relating to rules of origin, subsidies and countervailing measures etc. ${ }^{143}$ and such bodies, departments and services as may be established pursuant to the Customs law of the Community for purposes of administering the Customs Union; ${ }^{144}$

(b) Such institutions as may be established or authorized by the Council for purposes of administering the Common Market; ${ }_{145}^{15}$ and

(c) The East African Central Bank; ${ }^{146}$ institutions responsible for financial services (surveillance, compliance, enforcement) and statistics; and The East African Monetary Institute ${ }^{147}$ within the context of administering The East African Monetary Union.

\subsection{Challenges to the Institutional Framework}

Institutional and governance challenges associated with managing international organizations, such as Partner States' overemphasis on national sovereignties, inadequate resources, underdeveloped infrastructure and slow implementation of decisions face the Community's institutional framework. Critical among these are the excesses of the requirement of consensus in decision-making, interface challenges and challenges to the safeguarding of the Community's international status.

\subsubsection{Decision-Making by Consensus}

Decision making by the Summit and the Council and the making of recommendations by the Co-ordination Committee are guided by the principle of consensus. In the case of the Council, this applies to the making of policy

\footnotetext{
143 Protocol on the Establishment of the East African Community Customs Union, Article 24.

144 Ibid., Article 34 .

145 Protocol on the Establishment of the East African Community Common Market, Article 46 read together with Article $76(3)$ of the Treaty.

146 Protocol on the Establishment of the East African Community Monetary Union, Article 20.

147 Ibid., Articles 21 and 23 respectively.
} 
decisions, directives and regulations pertaining to the development and progression of the integration process as provided under the Treaty. In this regard, the Treaty provides that-

(a) "for purposes of the discharge of functions, the decisions of the Summit shall be by consensus"; 148 and

(b) "subject to a Protocol on decision-making the decisions of the Council shall be by consensus". 149

The Protocol on Decision Making by the Council provides that-

1. The decisions of the Council on the following matters shall be by consensus:

(a) Granting of observers status to an inter-governmental organization or civil society organization;

(b) Making of the financial rules and regulations of the Community;

(c) Submission of the annual budget of the Community to the Legislative Assembly;

(d) Approval of the expenditures of the Community;

(e) Establishment of any sectoral council or committee under the Treaty;

(f) Submission of Bills to the East African Legislative Assembly;

(g) Policy decisions made pursuant to Article 14(3) (a) of the Treaty;

(h) Decisions on what should be recommended to the Summit on:

(i) Amendment of the Treaty;

(ii) Approval or amendment of any protocol;

(iii) Admission of new members

(iv) Imposition of sanctions;

(v) Suspension of a member;

(vi) Transformation into a political federation; and

(vii) Expansion of areas of co-operation.

2. All other decisions of the Council shall be by simple majority. 150

The requirement on consensus has been replicated in the Rules of Procedure for the Summit, the Council and the Coordination Committee. ${ }^{151}$ Accordingly,

\footnotetext{
148 Ibid., Article 12(3).

149 Ibid., Article 15(4).

150 Article 2.

151 See Rule 13 of the Rules of Procedure of the Summit, Rule 13 of the Rules of Procedure of the Council and Rule 13 of the Rules of Procedure of the Co-ordination Committee (which apply mutatis mutandis to all lower committees and bodies).
} 
this requirement directs the making of all institutional or organizational policy decisions (which create direct obligations on the organs and institutions) and all operational decisions (which are necessitated by the Community's direct and substantive operations).

The Treaty does not define the term "consensus" in terms of, for example unanimity, or absolute, simple, qualified or other majority. However, the Court has given guidance as to the definition of consensus within the Community framework: "a general agreement among the members of a given group or community, each of which exercises some discretion in decision making agreements. Achieving consensus requires serious treatment of every group member's considered opinion. Once a decision is made it is important to trust in members' discretion in follow-up action. In the ideal case, those who wish to take up some action want to hear those who oppose it, because they count on the fact that the ensuing debate will improve the consensus. In theory, action without resolution of considered opposition will be rare and done with attention to minimize damage to relationships."152

Consensus as applied in the Treaty and protocols is not only a decisionmaking mechanism at the policy level for the Summit and the Council and in the other executive organs of the Community; it is also a mechanism that emphasises "all Partner States' representation" for a quorum at all meetings. ${ }^{153}$

The context of the Protocol on Decision Making suggests that all key policy matters such as the transformation of the integration process into a political federation or achieving key milestones like the Customs Union, the Common Market, the Monetary Union and institution building have to be arrived upon on the basis of consensus. Any EAC framework in such areas necessitates prior agreement/consensus by all the Partner States. Mwapachu has observed that "this protocol could have set out, as in the European Union, a matrix of issues that would require different forms or modalities of decision-making - unanimity, consensus, qualified majority etc. Unfortunately and given the backdrop of the demised EAC and the remaining excess baggage in the Partner States regarding issues of differential stages of economic development, the protocol retained a strict requirement for all decisions made by the Council".154

The only significant exception to the preponderance of consensus in decision-making is in respect of suspension or expulsion of a Partner State in case

\footnotetext{
$15^{2}$ EACJ Application No. 1 of 2008, p. 29.

153 Rules of Procedure.

154 Op. cit., footnote 9o, p. 57. See on different forms of decision making in the EU also EU chapter 2, and for the crucial importance of decision making by Qualified Majority Voting for the internal market, EU chapter 9 .
} 
of failure to observe and fulfill the fundamental principles and objectives of the Treaty or gross and persistent violation of such principles and objectives. ${ }^{155}$

As elaborated by Schermers and Blokker, decision-making by consensus ensures "general acclamation" or "common feeling" or "concurrence of feelings", acknowledges differences in power and interests and obviates "majoritarianism"; it has therefore been adopted bymanyinternational organizations. ${ }^{156}$ However, as has often been the case in the Community, it is a time-consuming method in which decisions may often have their intention watered down. It is also over-tied to "all Partner States' representation" for a quorum at meetings.

\subsubsection{Interface Challenges}

The achievement of the objectives of the Community depends on how cohesive and co-ordinated the organs and institutions are in the discharge of their respective functions. Although the Treaty and relevant protocols spell out the different functions of the organs and institutions, a primary or literal interpretation of the Treaty suggests that the intention of the Partner States, as contracting parties, is that the organs and institutions should play their roles with one ultimate objective-development of the Community for the benefit of the people of East Africa. Therefore, the introduction and maintenance of a mechanism for cordial and collaborative inter-facing and inter-relationships between the organs and institutions is unassailable.

Besides providing for the applicability of the principle of asymmetry and requiring the Secretariat to establish "practical working relations with the Court and the Assembly"157 the Treaty does not establish a mechanism for intra-organ/institution collaboration. With the Assembly, the Council and the Court each vying for optimum discharge of obligations, misunderstandings and institutional clashes do occur. Therefore, collaboration is more of an outcome of necessity in given cases than a substratum for regular operations. Regrettably, collaboration is not seen in the practice of the EAC and clashes between the different organs and institutions are evident, for example, the Assembly allowing a motion on a Bill like the Lake Victoria Basin Commission Bill which is not supported by the Councili ${ }^{158}$ or the Assembly enacting Bills such as the East African Community Trans-Boundary Ecosystem Management Bill 2011, the East African Community Polythene Materials Control Bill 2011, the East African Community Human and Peoples' Rights Bill 2011, the East African

\footnotetext{
155 Article 148.

${ }_{15} 6$ Henry G. Schermers and Niels M. Blokker (1995), International Institutional Law, Martinus Nijhoff Publishers, The Hague, pp. 505-885.

157 Article 71(1)(o).

$15^{8}$ Op. cit., footnote 9o, p. 145.
} 
Community HIV and AIDS Prevention and Management Bill 2012 and the East African Service Commission Bill 2010, all of which have not been assented to by the Summit.

Moreover, lack of a clear collaborative basis has the potential to generate unnecessary duplication of efforts among the organs and institutions. Since this challenge arises out of the fact that each organ pursues the accomplishment of its mandate to the best of its ability, the panacea lies in overall institutional review and amendment of the Treaty.

\subsubsection{Challenges to the Safeguarding of the Community's International Status}

It is part of jus cogens that for purposes of effectively discharging their functions "international organisations should be entitled to the grant of privileges and immunities for their assets, properties and representatives". ${ }^{159}$ The Treaty recognizes the international legal personality of the Community and invariably the Community's institutional framework. ${ }^{160}$ In this regard, the Treaty cognizant of the Community's legal capacity as a body corporate with perpetual succession, provides that-

(a) the Community shall enjoy international legal personality; ${ }^{161}$ and that

(b) persons employed in the service of the Community including staff, experts and consultants shall enjoy immunities and privileges while performing services to the Community. ${ }^{162}$

In practice the realization of the international status is afflicted by both the Partner States' insistence on national sovereignty and, a fortiori, their reluctance to agree on a common platform premise on the nature and extent of immunities and privileges. As a result the conclusion of headquarters agreements as bases for the grant of immunities and privileges for Community organs, institutions, staff and other persons in the employ of the Community remains largely streaked from one Partner State to another country to country. This is notwithstanding the Secretariat's long outstanding proposal for the conclusion of a protocol that would be a common yardstick for the conclusion of such agreements.

\footnotetext{
159 Malcolm N. Shaw (1997), International Law, Cambridge University Press, Cambridge, pp. 923-929.

16o Articles 138 read together with Articles 4 and 8 .

161 Ibid.

162 Article 73 read together with Article 72.
} 